\title{
Tripartite Risk Game Analysis on Public Private Partnership Projects of High-Speed Rail from the Perspective of Bank
}

\author{
Xing Yang*, Kehu Tan \\ School of Economics and Management, Beijing Jiaotong University, Beijing 100044, China
}

Corresponding Author Email: 14113093@bjtu.edu.cn

https://doi.org/10.18280/ijsse.100505

Received: 17 April 2020

Accepted: 8 August 2020

\section{Keywords:}

railway transport, risk-sharing mechanism, tripartite game, bank, public private partnership $(P P P)$ projects, risk factors

\begin{abstract}
The bank is a leading funder and a primary risk bearer in public private partnership (PPP) projects of high-speed rail (HSR). This paper explores the risk sharing of HSR PPP projects among three parties: the public sector, the private sector, and the bank. From the perspective of the bank, a comprehensive risk evaluation index system (EIS) was established, involving 37 risk factors in 4 stages. Meanwhile, the fuzzy evaluation method was used to calculate the center of gravity (COG) values. On this basis, a tripartite static game model was established based on risk preference. Then, the equilibrium point set of risk sharing was summarized by analyzing the payment matrix of the game. The results show that the bank-oriented comprehensive EIS for the risks in HSR PPP projects can effectively reduce the bank's capital risk, and the reasonable risk sharing among the three parties is greatly affected by the game mechanism based on risk preference and deterrent effect.
\end{abstract}

\section{INTRODUCTION}

In the last two decades, China has witnessed a boom in highspeed rail (HSR), and leapt to the first place in the world in terms of HSR mileage. It is estimated that, during 2021-2025, the HSR mileage in China will reach about $38,000 \mathrm{~km}$. Currently, many HSR projects are raising fund or under construction. The rapid development of HSR brought a huge funding gap. To bridge the gap, China starts to pilot public private partnership (PPP) projects of HSR in developed areas with concentrated passenger flows, namely, Jinan-Qingdao HSR, Hangzhou-Shaoxing-Taizhou HSR, and NanchangJiujiang HSR, aiming to attract various social capitals to HSR construction.

However, HSR PPP projects face multiple complex risks, owing to the particularity of the PPP model and HSR projects. On the one hand, the PPP model is a typical incomplete contract. Serious contract risks will occur, in the absence of a fair and reasonable mechanism for benefit distribution, risk sharing, and project supervision among all parties of the project.

On the other hand, HSR projects are inherently monopolistic, and capital intensive. As a public product, HSR is unlikely to bring a profit in the short term. Due to asset specificity, HSR projects require high investment in railway and equipment, which are difficult to dispose. In strong positions, China National Railway Group and local governments might collude to breach the contract, and force the bank to extend or renew the loan, or refunacing behavior, postponing the potential risks. For these reasons, the bank, as the key fund provider of the PPP model, often serves as the last risk bearer in HSR PPP projects of China. The public and private sectors transfer too many risks to the bank, causing huge losses to bank assets. To create a win-win for the public sector, the private sector, and the bank, it is important to establish a reasonable tripartite risk-sharing mechanism for HSR PPP projects.

Many scholars have investigated the risk sharing of PPP projects. Grimsey and Lewis [1], Bing et al. [2], Alkaf and Karim [3], and Chohra et al. [4] reviewed the main literature on PPP project risks, and prepared risk lists of PPP projects from different dimensions: macroscale, mesoscale, microscale, public finance, politics, law, finance, and management. Wang et al., Robert B. [5, 6], Liao [7], and Li [8] explored quantitative risk assessment methods like sensitivity analysis, decision tree (DT), Monte-Carlo (MC) simulation, and fuzzy comprehensive evaluation (FCE), measured the main risk factors of PPP projects in a comprehensive manner, and ranked them by the degree of impact. Rutgers and Haley [9], Crampes and Estache [10], Medda [11], Lam et al. [12], Humpherys et al. [13], Wang et al. [14] established static and dynamic game models by game theory, successfully explored various factors in risk sharing between government and enterprise in PPP projects (e.g. risk preference of project parties, symmetry between income and risk, information completeness, symmetry between party positions, optimal risk allocation, and pros and cons of risk allocation), and suggested dividing risk responsibility according to residual control rights, risk-taking ability, and risk-taking willingness.

On this basis, Ke et al. [15], and Qi et al. [16] analyzed the Channel Tunnel, Taiwan HSR, Spanish high-speed AVE, and TGV in France, drew lessons from the failed risk sharing cases of international HSR PPP projects, and provided policy recommendations for the risk-sharing mechanism of China's HSR PPP projects. Their research suggests that the failure of PPP projects could be attributed to the unreasonable design of the risk-sharing structure, the radicalness of the financing method, the insufficient operating capacity of the private sector, as well as the slack supervision or over-management by the government. To prevent the failure, the government 
needs to bear the risks brought by ensuring market fairness, regulatory management, financial guarantees, and legal changes; the special purpose vehicle (SPV) company needs to undertake the risks incurred by project financing, construction, operation, and maintenance; the bank needs to assume part of the project financing risks, mainly including credit risk, interest rate risk, and liquidity risk.

The above literature focuses more on the risk-sharing mechanism between public and private sectors, overlooking the fact that the bank shares much of the risks and ultimately takes the risks through the provision of loans and other financial services. The existing game models mainly concern the game between public and private sectors. There is no report dealing with the tripartite game from the perspective of banks.

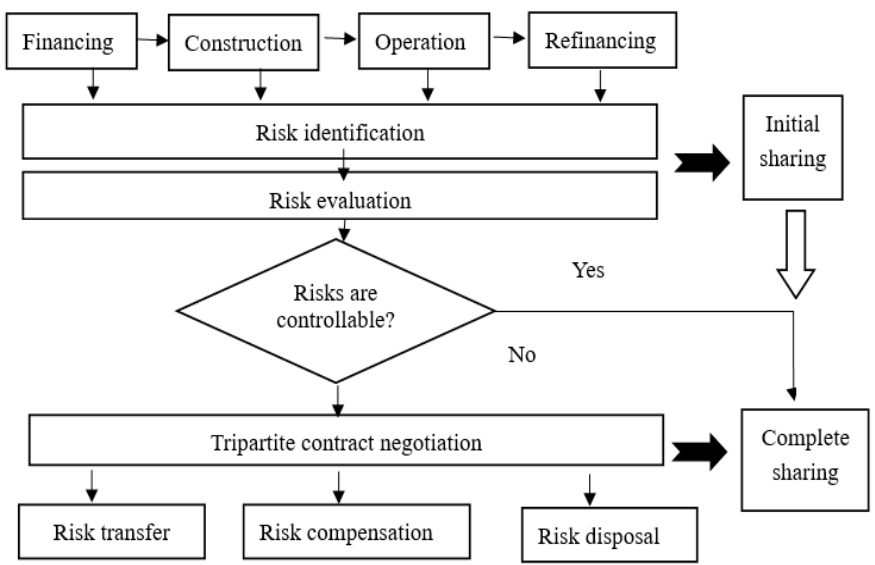

Figure 1. The technical roadmap for exploring the risksharing mechanism of HSR PPP project from the perspective of the bank
Therefore, this paper makes two important innovations: First, the risks of HSR PPP projects were re-evaluated and classified through analytic hierarchy process (AHP), a risk evaluation system (EIS) was established for HSR PPP projects, and the selected indices were ranked by the degree of impact on the bank. Second, the relationships among public sector, private sector, and bank were analyzed from the perspective of the bank, a tripartite static game model was constructed under information symmetry, and the equilibrium points were derived for the risk game of HSR PPP projects. The research results provide a reference for the risk sharing in China's HSR PPP projects, and lay the basis for the bank to prevent risks and select projects. The technical roadmap of this research is illustrated in Figure 1.

\section{EIS CONSTRUCTION}

Based on the risk features of different stages in HSR PPP projects, this paper divides each project into four stages from the perspective of the bank: financing, construction, operation, and refinancing. A total of 37 risks were summarized, and compiled into an EIS for HSR PPP projects (Table 1).

Drawing on the principles of PPP model risk assessment proposed by Rutgers and Haley [17], Iyer and Sagheer [18], and The World Bank [19], this paper fully considers the following four principles in the EIS construction:

(1) Risk symmetry

All parties of an HSR PPP project call for fairness. The share of risk allocated to a party must match its benefits. Thus, it is necessary to consider the risk factors that have an immense impact on bank profits, such as construction quality and market income.

Table 1. The bank-oriented EIS of HSR PPP projects

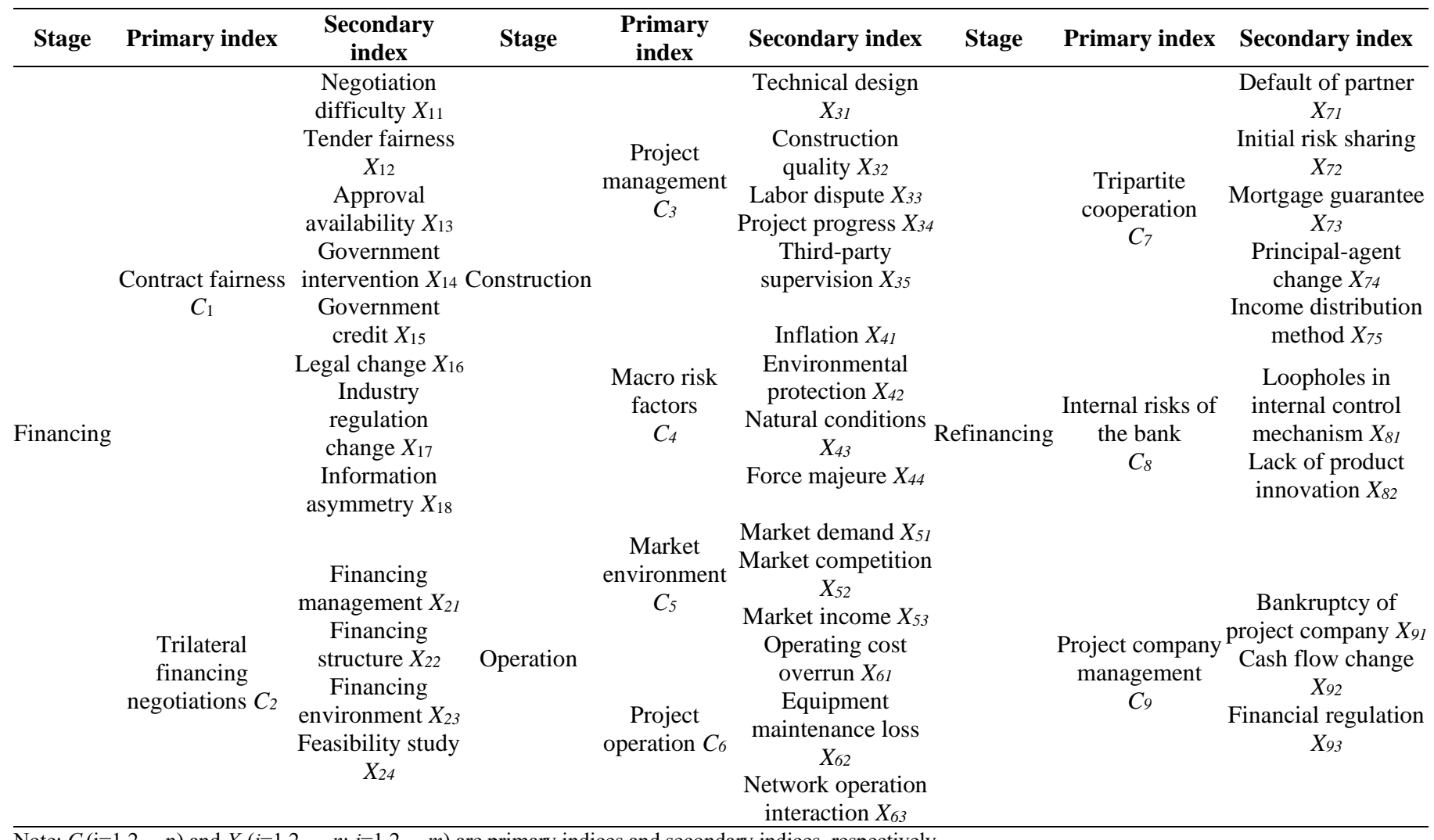

Note: $C_{\mathrm{i}}(\mathrm{i}=1,2, \ldots \mathrm{n})$ and $X_{i j}(i=1,2, \ldots n ; j=1,2, \ldots m)$ are primary indices and secondary indices, respectively. 
(2) Minimal risk cost

In essence, the purpose of the bank to invest in HSR PPP projects is to obtain long-term benefits, while bearing the minimal risk cost. Thus, it is necessary to consider the risk factors that greatly affect the capital cost of the bank, such as financing structure and inflation.

(3) Limited risk sharing

The bank can tolerate some non-performing assets, and even delay or defuse risks through debt-to-equity swaps, asset securitization, etc. But the risks that can be borne by the bank are not unlimited. If the risks of an HSR PPP project cause huge loss, the project might fail or go bankrupt. In this case, the bank will face enormous risks and even bankruptcy. Therefore, it is necessary to consider risk factors that bear on the risk sharing of the bank, such as financing management, and bankruptcy of project company.

\section{(4) Dynamic risk sharing}

The bank's investment plan is not fixed. When the internal and external conditions change, the three parties need to renegotiate the risk-sharing plan, and adjust the investment plan accordingly. Hence, it is necessary to consider risk factors that have a large impact on the bank's investment plan, such as default of partner and principal-agent change.

\section{RISK EVALUATION}

A Delphi survey was conducted among sub-branch managers and credit managers responsible for HSR PPP projects. A total of 500 questionnaires were released, and all were effectively collected. Experts were invited to make objective judgement of the degree of impact from each risk factor on bank operators. Then, the FCE was carried out to quantify the subjective evaluations of the respondents, and solve the center of gravity (COG) values of the risk factors of HSR PPP projects.

\subsection{Creating a set of indices for risk factors}

Considering the bank-oriented EIS for HSR PPP projects, the set of secondary indices for risk factors was constructed as $X_{i j}=\left\{X_{i 1}, X_{i 2}, \ldots X_{i j}\right\}$, where the risk factors are independent of each other, that is, $X_{i} \cap X_{j}=\phi(i \neq j)$.

\subsection{Constructing a judgement matrix and solving the weight vectors}

Table 2. The criteria for relative importance rating

\begin{tabular}{cc}
\hline Score & Criteria \\
\hline 1 & $\begin{array}{c}\text { Two risk factors have the same degree of impact on the } \\
\text { bank. }\end{array}$ \\
3 & $\begin{array}{c}\text { One risk factor has slightly greater impact on the bank } \\
\text { than the other factor. }\end{array}$ \\
5 & $\begin{array}{c}\text { One risk factor has moderately greater impact on the } \\
\text { bank than the other factor. }\end{array}$ \\
7 & $\begin{array}{c}\text { One risk factor has strongly greater impact on the bank } \\
\text { than the other factor. }\end{array}$ \\
9 & $\begin{array}{c}\text { One risk factor has extremely greater impact on the bank } \\
\text { than the other factor. }\end{array}$ \\
$2,4,6,8$ & Intermediate values \\
\hline
\end{tabular}

Through the AHP, a judgement matrix was established for pairwise comparison between secondary risk factors, and used to compute the relative importance of each factor. First, the index set $X_{i j}=\left\{X_{i 1}, X_{i 2}, \ldots X_{i j}\right\}$ was analyzed, the importance of each factor on each layer was compared in pairs, and summarized into a judgement matrix A:

$$
\mathrm{A}=\left[\begin{array}{ccccc}
a_{11} & a_{12} & a_{13} & \cdots & a_{1 j} \\
a_{21} & a_{22} & a_{23} & \cdots & a_{2 j} \\
a_{31} & a_{32} & a_{33} & \cdots & a_{3 j} \\
\vdots & \vdots & \vdots & \vdots & \vdots \\
a_{i 1} & a_{i 2} & a_{i 3} & \cdots & a_{i j}
\end{array}\right]
$$

where, $a_{i j}$ is a secondary index. The relative importance of $a_{i j}$ was rated against the criteria in Table 2.

After calculating the maximum eigenvalue $\lambda_{\max }$ of judgment matrix A and its corresponding normalized eigenvector $W=\left(w_{1}, w_{2}, \ldots w_{\mathrm{n}}\right)^{T}$, it can be derived that $A W=\lambda_{\max } W$. The resulting eigenvector $W=\left(w_{1}, w_{2}, \ldots w_{\mathrm{n}}\right)^{T}$ is the weight vector of the corresponding evaluation unit. The maximum eigenvalue $\lambda_{\max }$ can be obtained by:

$$
\lambda_{\max }=\sum_{i=1}^{n} \frac{(A W)_{i}}{n w_{i}}
$$

\subsection{Consistency test of judgment matrix}

The judgement matrix $A$ is consistent if $a_{i j}=\frac{a_{i k}}{a_{j k}}$. The consistency of this matrix was tested in the following steps:

Step 1. Calculate the consistency index $C I=\frac{\lambda_{\max }}{n-1}$, where $\mathrm{n}$ is the order of the judgment matrix.

Step 2. Calculate the average random consistency index RI, which is the arithmetic mean of repeatedly calculated eigenvalues of the judgment matrix. The RI values by the scale method are listed in Table 3.

Step 3. Calculate the consistency ratio $C R=\frac{C I}{R I}$. If $C R<0.1$, the matrix has acceptable consistency, i.e. the matrix is in line with the reality; Otherwise, the matrix deviates greatly from the reality.

Table 3. The RI values by the scale method

\begin{tabular}{cccccccccc}
\hline Order & $\mathbf{1}$ & $\mathbf{2}$ & $\mathbf{3}$ & $\mathbf{4}$ & $\mathbf{5}$ & $\mathbf{6}$ & $\mathbf{7}$ & $\mathbf{8}$ & $\mathbf{9}$ \\
\hline$R I$ & 0.00 & 0.01 & 0.38 & 0.80 & 1.05 & 1.19 & 1.23 & 1.37 & 1.42 \\
\hline
\end{tabular}

\subsection{Creating the judgement matrix of secondary indices relative to primary indices}

Each secondary risk factor was compared to each element in the set of primary indices $C_{i}=\left\{C_{1}, C_{2}, \ldots C_{9}\right\},\{i=1,2, \ldots, 9\}$, forming a pairwise judgement matrix $\mathrm{R}$ :

$$
R=\left(\begin{array}{cccc}
r_{11} & r_{12} & \cdots & r_{1 n} \\
r_{21} & r_{22} & \cdots & r_{2 n} \\
\cdots & \cdots & \cdots & \cdots \\
r_{q 1} & r_{q 2} & \cdots & r_{q n}
\end{array}\right)
$$

\subsection{Comprehensive risk evaluation}

The weight vectors $W$ of secondary index set was combined with the fuzzy evaluation set $R$ of primary indices to obtain the evaluation set of primary indices: 


$$
C=W * R=\left(W_{1}, W_{2}, \cdots W_{n}\right)\left(\begin{array}{c}
R_{1} \\
R_{2} \\
\vdots \\
R_{K}
\end{array}\right)
$$

Then, the fuzzy COG values of the evaluation indices for the risks of HSR PPP projects can be obtained (Table 4).

As shown in Table 4, government intervention, financing management, third-party supervision, and principal-agent change are high risk factors, which contribute greatly to the overall risk level. Peng Hongqin and Zhang Wuguo pointed out that, when a country's economy develops to a certain level, the growth of passenger and freight demands will both slow down. With the expanding scale of China's HSR, market demand, market income, and market competition become medium to high risk factors, making a relatively large contribution to the overall risk level. In addition, approval availability, environmental protection, and loopholes in internal control mechanism are medium to low risk factors, contributing little to the overall risk level.

Table 4. The fuzzy COG values of the evaluation indices for the risks of HSR PPP projects

\begin{tabular}{cccccc}
\hline Index & $\begin{array}{c}\text { Fuzzy COG } \\
\text { value }\end{array}$ & Index & $\begin{array}{c}\text { Fuzzy COG } \\
\text { value }\end{array}$ & Index & $\begin{array}{c}\text { Fuzzy COG } \\
\text { value }\end{array}$ \\
\hline$X_{11}$ & 2.46 & $X_{32}$ & 3.36 & & 3.12 \\
$X_{12}$ & 2.30 & $X_{33}$ & 2.36 & $X_{63}$ & 4.05 \\
$X_{13}$ & 2.13 & $X_{34}$ & 2.81 & $X_{71}$ & 4.16 \\
$X_{14}$ & 4.37 & $X_{35}$ & 4.11 & $X_{72}$ & 3.68 \\
$X_{15}$ & 2.30 & $X_{41}$ & 3.16 & $X_{73}$ & 4.12 \\
$X_{16}$ & 3.52 & $X_{42}$ & 2.01 & $X_{74}$ & 3.35 \\
$X_{17}$ & 3.56 & $X_{43}$ & 3.15 & $X_{75}$ & 2.12 \\
$X_{18}$ & 3.49 & $X_{44}$ & 3.56 & $X_{81}$ & 2.56 \\
$X_{21}$ & 4.16 & $X_{51}$ & 3.72 & $X_{82}$ & 2.89 \\
$X_{22}$ & 3.80 & $X_{52}$ & 3.81 & $X_{91}$ & 4.15 \\
$X_{23}$ & 3.78 & $X_{53}$ & 2.29 & $X_{92}$ & 3.88 \\
$X_{24}$ & 3.27 & $X_{61}$ & 2.15 & $X_{93}$ & \\
$X_{31}$ & 3.31 & $X_{62}$ & 2.56 & & \\
$C_{1}$ & $0.07<0.1$, & 0.17 & &
\end{tabular}

$\mathrm{CR}=0.07<0.1$, indicating that the judgement matrix is consistent.

\section{MODELING AND RESULTS ANALYSIS}

Based on the assessed EIS, it is assumed that the three parties are engaged in a completely static game. Xiong et al. [20] and Feuvre et al. [21] suggested that HSR PPP projects belong a typical incomplete contract model. That is, the project contract cannot cover every matter. Then, the party with information advantages has the motivation to obtain benefits through opportunistic behavior.

A successful PPP project must rationalize and balance the benefit distribution and risk sharing among all parties. In general, the public sector, with government background, often has high risk preference and deterrent effect; the private sector, sensitive to market factors, pays much attention to the riskreturn features of the project, and has moderate risk preference and deterrent effect; the bank, as the fund provider, is "hijacked" by the public nature of HSR PPP project, has low risk preference and deterrent effect, because it wants to make benefits from the project without facing unacceptable risks.

\subsection{Tripartite static game model}

4.1.1 Basic factors

(1) Parties: The parties refer to the main stakeholders of the
HSR PPP project, including the public sector, private sector, and bank.

(2) Game of complete information: Each party know all the information about the project, as well as the decision made by another party.

(3) Mutually independent risk factors: The risks of the project all have clear liability boundaries, and are not inherently correlated.

(4) Collusion: The public sector has absolute deterrent effect on the private sector and the bank, and can choose between two attitudes: agree and disagree. In response, the private sector and the bank often conspire to confront the public sector. Each party can choose between two attitudes toward risk taking: $\left(u_{1}, u_{2}\right) \in U_{\mathrm{i}}$ (take, not take).

(5) Utility: The risk income $G_{i}$ and risk cost $C_{i}$ of any party are related to risk factors. Suppose there are $\mathrm{m}$ risks $1,2, \ldots \mathrm{m}$ in the HSR PPP project. The j-th risk taken by the i-th party can be denoted as $R_{i}^{j}$, where $1 \leq i \leq 3,1 \leq j \leq 37$.

The income and cost of the ith party can be respectively expressed as:

$$
\begin{aligned}
& G_{i}=g_{i}\left(R_{i}^{1}, R_{i}^{2}, R_{i}^{3} \cdots R_{i}^{m}\right), i=1,2,3 \\
& C_{i}=c_{i}\left(R_{i}^{1}, R_{i}^{2}, R_{i}^{3} \cdots R_{i}^{m}\right), i=1,2,3
\end{aligned}
$$

Let $D$ be the utility, i.e. risk satisfactory of the ith party. The value of $D$ depends on the combined effect of risk preference and deterrent effect. If $D_{i}>0$, the i-th party takes the risk; otherwise, it does not take the risk:

$$
D_{i}=G_{i}-C_{i}, i=1,2,3
$$

(6) Equilibrium: According to the hypothesis of bounded rationality, it is assumed that the three parties collaborate closely with other each to maximize their utilities, and are expected to reach Nash equilibrium.

\subsection{Hypotheses}

Through the above analysis, the following hypotheses were made:

(1) The three parties are all rational economic men.

(2) Each party can only choose between "take" or "not take".

(3) The risk, income, and cost of each party are linear functions:

$$
\begin{aligned}
& G_{i}=g_{i}^{1} R_{\mathrm{i}}^{1}+g_{i}^{2} R_{\mathrm{i}}^{2}+g_{i}^{3} R_{\mathrm{i}}^{3}+\cdots g_{i}^{m} R_{\mathrm{i}}^{m}=\sum_{j=1}^{37} G_{i}^{j} R_{i}^{j}, i=1,2,3 \\
& C_{i}=c_{i}^{1} R_{\mathrm{i}}^{1}+c_{i}^{2} R_{\mathrm{i}}^{2}+c_{i}^{3} R_{\mathrm{i}}^{3}+\cdots c_{i}^{m} R_{\mathrm{i}}^{m}=\sum_{j=1}^{37} C_{i}^{j} R_{i}^{j}, i=1,2,3
\end{aligned}
$$

where, $g_{i}^{j}$ is the weight of the income of the i-th party taking the $\mathrm{j}$-th risk; $c_{i}^{j}$ is the weight of the cost of the $\mathrm{i}$-th party taking the $\mathrm{j}$-th risk.

Substituting (8) and (9) into (7):

$$
D_{i}=\sum_{j=1}^{m} G_{i}^{j} R_{i}^{j}-\sum_{j=1}^{m} C_{i}^{j} R_{i}^{j}=\sum_{j=1}^{37}\left(G_{i}^{j}-C_{i}^{j}\right) R_{i}^{j}, i=1,2,3
$$




\subsection{Model analysis}

When all three parties of the HSR PPP project face the same risk, i.e. $R_{1}=R_{2}=R_{3}, D_{i}$ depends on $G_{i} C_{i}, i=1,2,3$.

As mentioned before, the public sector has the decisionmaking power of the HSR PPP project. If the public sector chooses not to agree, then the utilities of all three parties are zeros. There is no need to analyze risk sharing. Hence, the public sector was assumed to choose agree. Then, the payment matrix of the game model can be established as Table 5 .

Table 5. The payment matrix of the tripartite static game

\begin{tabular}{|c|c|c|c|}
\hline \multirow[b]{2}{*}{ Index } & \multicolumn{3}{|c|}{$\begin{array}{cc}\text { Public sector taking risk } & \begin{array}{c}\text { Public sector not } \\
\text { taking risk }\left(u_{2}\right)\end{array}\end{array}$} \\
\hline & $\begin{array}{cc}\text { Bank taking } & \begin{array}{c}\text { Bank not } \\
\text { risk }\end{array} \\
\text { taking risk } \\
\left(\mu_{1}\right) & \left(\mu_{2}\right)\end{array}$ & $\begin{array}{c}\text { Bank } \\
\text { taking risk } \\
\left(\mu_{1}\right)\end{array}$ & $\begin{array}{l}\text { Bank not } \\
\text { taking risk } \\
\left(\mu_{2}\right)\end{array}$ \\
\hline $\begin{array}{c}\text { Private sector } \\
\text { taking risk } \\
\left(\mu_{1}\right)\end{array}$ & $\begin{array}{cc}\left(G_{1}-C_{1}, G_{2-}-\right. & \left(G_{1}-C_{1}, G_{2-}\right. \\
\left.C_{2}, G_{3}-C_{3}\right) & \left.C_{2}, 0\right)\end{array}$ & $\begin{array}{c}\left(0, G_{2}-C_{2}\right. \\
\left.\quad G_{3}-C_{3}\right)\end{array}$ & $\left(0, G_{2}-C\right.$ \\
\hline $\begin{array}{l}\text { Private sector } \\
\text { not taking risk } \\
\left(\mu_{2}\right)\end{array}$ & $\begin{array}{c}\left(G_{1}-C_{1}, 0,\right. \\
\left.\quad G_{3}-C_{3}\right)\end{array}$ & $\begin{array}{l}\left(0,0, G_{3-}\right. \\
\left.\quad C_{3}\right)\end{array}$ & $(0,0,0)$ \\
\hline
\end{tabular}

As shown in Table 5, the Nash equilibrium outcome ultimately depends on $G_{i}=C_{i}(i=1,2,3)$. The relevant outcomes fall into three categories:

When $G_{1}^{i}-C_{1}^{i}>0$, there are four Nash equilibrium points for the three parties: (take, take, take), (take, not take, take), (take, take, not take), and (take, not take, not take). In this case, the party with relatively large $G_{1}^{i}-C_{1}^{i}$ will take the risk.

When $G_{1}^{i}-C_{1}^{i} \leq 0$, and $G_{2}^{i}-C_{2}^{i}>0$ or $G_{3}^{i}-C_{3}^{i}>0$, there are three Nash equilibrium points for the three parties: (not take, take, take), (not take, take, not take), and (not take, not take, take). In this case, the public sector has negative utility and refuses to take risks; the party with relatively large utility between the private sector and the bank will take the risk.

When $G_{i}^{i}-C_{i}^{i} \leq 0$, all three parties have negative utilities, leaving only one Nash equilibrium point: (not take, not take, not take). In this case, no party is willing to take the risk.

The above eight Nash equilibrium points are displayed in Table 6 .

Table 6. The set of Nash equilibrium points of the tripartite static game

\begin{tabular}{|c|c|c|c|}
\hline $\begin{array}{c}\text { Set of Nash equilibrium } \\
\text { points }\end{array}$ & $G_{1}^{i}-C_{1}^{i}$ & $\begin{array}{l}\text { Utility } D_{i} \\
G_{2}^{i}-C_{2}^{i}\end{array}$ & $G_{3}^{i}-C_{3}^{i}$ \\
\hline Take, take, take & $>0$ & $>0$ & $>0$ \\
\hline Take, take, not take & $>0$ & $>0$ & $\leq 0$ \\
\hline Take, not take, take & $>0$ & $\leq 0$ & $>0$ \\
\hline Take, not take, not take & $>0$ & $\leq 0$ & $\leq 0$ \\
\hline Not take, take, take & $\leq 0$ & $>0$ & $>0$ \\
\hline Not take, take, not take & $\leq 0$ & $>0$ & $\leq 0$ \\
\hline Not take, not take, take & $\leq 0$ & $\leq 0$ & $>0$ \\
\hline Not take, not take, not take & $\leq 0$ & $\leq 0$ & $\leq 0$ \\
\hline
\end{tabular}

Table 7. The responsibility for the main risks of HSR PPP projects

\begin{tabular}{|c|c|c|c|c|c|c|c|}
\hline \multicolumn{2}{|c|}{ Financing } & \multicolumn{2}{|c|}{ Construction } & \multicolumn{2}{|c|}{ Operation } & \multicolumn{2}{|c|}{ Refinancing } \\
\hline Risk factor & $\begin{array}{l}\text { Responsible } \\
\text { party }\end{array}$ & Risk factor & $\begin{array}{l}\text { Responsible } \\
\text { party }\end{array}$ & Risk factor & $\begin{array}{l}\text { Responsible } \\
\text { party }\end{array}$ & Risk factor & $\begin{array}{l}\text { Responsible } \\
\text { party }\end{array}$ \\
\hline $\begin{array}{l}\text { Negotiation } \\
\text { difficulty }\end{array}$ & Three parties & Technical design & Single party & Market demand & Two parties & $\begin{array}{l}\text { Income distribution } \\
\text { method }\end{array}$ & Three parties \\
\hline Tender fairness & Two parties & $\begin{array}{l}\text { Construction } \\
\text { quality }\end{array}$ & Single party & Market competition & Single party & Cash flow change & Single party \\
\hline $\begin{array}{l}\text { Approval } \\
\text { availability }\end{array}$ & Single party & Labor dispute & Single party & $\begin{array}{l}\text { Operating cost } \\
\text { overrun }\end{array}$ & Single party & Initial risk sharing & Three parties \\
\hline $\begin{array}{l}\text { Financing } \\
\text { management }\end{array}$ & Single party & Project progress & Three parties & Market income & Single party & Default of partner & Default party \\
\hline $\begin{array}{l}\text { Financing } \\
\text { structure }\end{array}$ & Single party & $\begin{array}{l}\text { Third-party } \\
\text { supervision }\end{array}$ & Single party & $\begin{array}{c}\text { Equipment } \\
\text { maintenance loss }\end{array}$ & Single party & Principal-agent change & Three parties \\
\hline $\begin{array}{l}\text { Financing } \\
\text { environment }\end{array}$ & Two parties & Inflation & Three parties & $\begin{array}{l}\text { Network operation } \\
\text { interaction }\end{array}$ & Single party & Mortgage guarantee & Two parties \\
\hline Feasibility study & Two parties & $\begin{array}{l}\text { Environmental } \\
\text { protection }\end{array}$ & Two parties & & & $\begin{array}{l}\text { Loopholes in internal } \\
\text { control mechanism }\end{array}$ & Single party \\
\hline $\begin{array}{l}\text { Information } \\
\text { asymmetry }\end{array}$ & Three parties & Natural conditions & Single party & & & $\begin{array}{l}\text { Lack of product } \\
\text { innovation }\end{array}$ & Single party \\
\hline $\begin{array}{l}\text { Government } \\
\text { intervention }\end{array}$ & Single party & Force majeure & Three parties & & & Financial regulation & Single party \\
\hline Government credit & Single party & & & & & $\begin{array}{l}\text { Bankruptcy of project } \\
\text { company }\end{array}$ & Three parties \\
\hline $\begin{array}{c}\text { Legal change } \\
\text { Industry regulation } \\
\text { change }\end{array}$ & $\begin{array}{l}\text { Three parties } \\
\text { Three parties }\end{array}$ & & & & & & \\
\hline
\end{tabular}

The game analysis shows that risk satisfaction is the key index for risk sharing in HSR PPP projects. In China, the HSR construction is dominated by state-owned capital. Thus, the public sector, with a high risk satisfaction and a strong deterrent effect, tends to transfer and share project risks to other parties, especially the bank. This is because the bank is closely supervised by the government, required to serve the economic and social goals of the region, and blessed with the means to postpone risk exposure. For example, the banking industry invested heavily in HSR projects, as a part of the 4 trillion investment package following 2008. However, only a few HSR projects have made profits, namely, BeijingShanghai HSR, Beijing-Tianjin Intercity HSR, ShanghaiHangzhou HSR, Shanghai-Nanjing HSR, and ShenzhenHangzhou HSR. Most HSR projects have been operating at a loss, failing to repay the principal and interest. As a result, the 
heavy investment only brings a huge amount of nonperforming loans to the banking industry. Another example is the default by Northeast Asia Railway Group Co., Ltd., Jilin Province, resulting in a $151.8 \%$ increase (RMB 500 million yuan) in non-performing loans to Changchun Development Rural Commercial Bank that year. Admittedly, the Chinese government has proposed multiple ways to dispose of the nonperforming assets formed by HSR projects, such as asset securitization and debt-to-equity swaps. But the exploratory measures have not formed a scale effect.

\subsection{Responsibility for the main risks of HSR PPP projects}

From the perspective of the bank, the responsibility for the main risk factors (Table 7) was preliminarily allocated based on the risk evaluation and game results.

In practice, the public sector, private sector, and bank can basically share the risks based on risk satisfaction for the risk factors whose responsibility is clearly stipulated, namely, approval availability, equipment maintenance loss, and loopholes in internal control mechanism. If a risk factor needs to be shared between two or three parties, the three parties should reach an equilibrium on a rational interval of share ratios. Within the interval, the three parties can share resources, and cooperate with each other orderly, and realize relatively fair allocation of benefits and risks, according to the principle of "value for money" and residual control rights.

\section{CONCLUSIONS}

HSR PPP projects adopt a typical contract. The main participants are the public sector, private sector, and bank. However, the risk sharing in HSR PPP projects is impeded by the difficulty in defining the risk types. Moreover, excessive risk transfer might occur, due to the asymmetric states and deterrent effects of different parties. From the perspective of the bank, this paper selects 37 main risk factors of the bank in HSR PPP projects, calculates the fuzzy COV values of these factors through FCE, and divides the factors into high, medium, and low risk levels. On this basis, a static game model of the public sector, private sector, and bank was established under information symmetry. Assuming that all three parties are rational economic men, eight Nash equilibrium points were obtained, the main principles were drawn for the rational risk sharing among the three parties, and the responsibility of risk factors was preliminarily allocated from the angle of the bank. Based on our results, banks can prepare effective risk-sharing plans, and realize early warning and prevention of risks in HSR PPP projects.

\section{REFERENCES}

[1] Grimsey, D., Lewis, M.K. (2004). Public Private Partnerships: The Worldwide Revolution in Infrastructure Provision and Project Finance. UK, Edward Elgar Publishing Limited.

[2] Bing, L., Akintoye, A., Edwards, P.J., Hardcastle, C. (2010). The allocation of risk in PPP/PFI construction projects in the UK. International Journal of Project Management, $16(10)$ : https://doi.org/10.1016/j.ijproman.2004.04.006

[3] Alkaf, N., Karim, A. (2011). Risk allocation in PublicPrivate Partnership (PPP) Project: A review on risk factors. International Journal of Sustainable Construction Engineering \& Technology, 2(2): 5-8.

[4] Chohra, M., Mu, S., Cheng, H. (2011). Risks and new transformations of PPP contracts. Journal of Southeast University, 12(4): 458-462. https://doi.org/10.3969/j.issn.1003-7985.2011.04.022

[5] Wang, S.Q., Tiong, R., Ting, S.K., Ashley, D. (2006). Evaluation and management of foreign exchange and revenue risks in China's BOT projects. Construction Management and Economics, 18(2): 197-207. https://doi.org/10.1080/014461900370825

[6] Robert, B. (2009). Integrated Quantitative Risk Management Symposium Sponsored by the USAF. SMC and Aerospace Corporation, 1: 7-10.

[7] Liao, S.N. (2010). Comparison of quantitative risk assessment methods for PPP projects. Co-Operative Economy \& Technology, 30-31. https://doi.org/10.3969/j.issn.1672-190X.2010.11.015

[8] Li, L. (2012). Financing risk assessment of BOT-TOTPPP projects based on risk matrix. Journal of Kunming University of Science and Technology (Social Science Edition), 12(1): 74-79. https://doi.org/10.3969/j.issn.1671-1254.2012.01.014

[9] Rutgers, J.A., Haley, H.D. (1996). Project risks and risk allocation. Cost Engineering, 38(9): 27-30.

[10] Crampes, C., Estache, A. (1998). Regulatory trade-offs in the design of concession contracts. Utilities Pollicy, 7(1): $\quad 1-13$. https://doi.org/10.1016/S09571787(98)00003-4

[11] Medda, F. (2007). A game theory approach for the allocation of risks in transport public private partnerships. International Journal of Project Management, (25): 791798. https://doi.org/10.1016/j.ijproman.2006.06.003

[12] Lam, K.C., Wang, D., Lee, P.T.K., Tsang, Y.T. (2007). Modelling risk allocation decision in construction contracts. International Journal of Project Management, 25(5): https://doi.org/10.1016/j.ijproman.2006.11.005

[13] Humphreys, I.M., Francis, G, Ison, S. (2002). An examination of risk transference in air transport privazation. Transportation Quarterly, 57(4): 31-37. https://doi.org/10.1061/(ASCE)0733947Z(2002)128:2(182)

[14] Wang, W.J., Peng, X., Wang, B., Qiu, S. (2018). An optimization model for PPP project risk sharing game based on risk preference. Engineering Economy, 2018(2): 31-35.

[15] Ke, Y.J., Wang, Y.J., Chen, B.Q. (2008). Enlightenment of the failure of the channel tunnel to PPP project risk sharing. China Civil Engineering Journal, 19(12): 41-43. https://doi.org/10.3321/j.issn:1000-131X.2008.12.016

[16] Qi, J.G., Yun, Y., Dan, J.L. (2015). Analysis on the financial risks of banks in PPP projects. China Banking, 19(10): 25-30. CNKI: SUN: ZGBK.0.2015-10-028

[17] Rutgers, J.A., Haley, HD. (1996). Project risks and risk allocation. Cost Engineering, 38(9): 27-30.

[18] Iyer, K.C., Sagheer, M. (2010). Hierarchical structuring of PPP risks using interpretative structural modeling. Journal of Construction Engineering and Management, 136(2): 151-159.

[19] World Bank: Public-Private Partnership Reference $\begin{array}{llll}\text { Guide } & \text { version } & 2.0 & \text { [R]. }\end{array} 2014$. http://hdl.handle.net/10986/29052.

[20] Xiong, W., Yuan, J.F., Li, Q., Skibniewski, M.J. (2015). 
Performance objective-based dynamic adjustment model to balance the stakeholders' satisfaction in PPP projects. Journal of Civil Engineering and Management, 21(5): 539-547.

https://doi.org/10.3846/13923730.2014.895409
[21] Feuvre, M.L., Medway, D., Warnaby, G., Ward, K., Goatman, A. (2016). Understanding stakeholder interactions in urban partnerships. Cities, 52(5): 55-65. https://doi.org/10.1016/j.cities.2015.10.017 